\title{
Why the Law is Equivalent and, as a Rule, Injustice
}

\author{
Vladimir M. Syrykh* \\ Russian State University of Justice \\ 69 Novocheremushkinskaya Str., \\ Moscow, 117418, Russia
}

Received 07.02.2017, received in revised form 21.02.2017, accepted 20.03.2017

The article justifies the illegitimacy of views in the legal literature on justice as an essential feature of law: recognition of its universality is excluded, since the subject of legal regulation is not limited to the sphere of validity of the principle of justice, and certain legal relations do not correspond to it at all (for example, technical, production, educational, procedural relations, etc.). Objects of legal relations, in the name of which citizens and other persons enter into legal relations, are not equal, but equivalent. The principle of equivalence is manifested in cases when the value of the material or spiritual benefit obtained by the subject of a legal relation corresponds to the costs that it incurred in the process of fulfilling a legal obligation in this legal relation. At the same time, a significant part of property and other legal relations directly contradicts the principle of justice.

Keywords: philosophy of law, law, principles of law, justice, equivalence, private law, public law, morality, anti-law.

DOI: 10.17516/1997-1370-0069.

Research area: philosophy, law.

In legal literature, one of the essential features of law is often called justice. V.S. Nersesiants generally does not see the law outside of justice. In his opinion, only the law is fair. He notes, "What expresses the law, corresponds to the law and follows the law is just. To act with justice means to act lawfully, according to the universal and equal requirements of law". His position is justified by the fact that in the context of the natural-legal definition, justice is traditionally understood as retribution of the equal for the equal (Nersesiants, 1998, pp. 29, 30). Meanwhile, recognition of the principle of justice as a universal essential feature of the law is problematic due to the fact that: 1) the subject of legal regulation is much broader than the scope of justice in the law; 2) there is a number of legal relations that do not meet the requirements of justice.

The law, according to which equal is given for the equal, clearly reveals itself only in the talion ("an eye for an eye, a tooth for a tooth"). However, at the later stages of legal development, such an understanding of justice was found to be inaccurate and was replaced by the principle of "equivalence". The replacement took place

\footnotetext{
(C) Siberian Federal University. All rights reserved

* Corresponding author E-mail address: svm27@mail.ru
} 
in the simplest and historically first economic relationship of exchange.

The participants in the exchange had no need to enter into a legal relation so that the existing thing could be exchanged for another such thing, because only under this condition the principle of "equal for the equal" is preserved. Other motives form the basis of the exchange - to obtain the ownership of a thing that the subject does not have, but recognizes it as vitally necessary and, in order to satisfy this need, is ready to give an equivalent but different thing. A canvas is exchanged for grain, a tool of labour for jewellery. In any case, different things can be objects of the exchange and by virtue of this; the exchange can only be equivalent, but not equal for equal. In this case, equivalence may have certain fluctuations in one direction or another, the subject may be wrong in estimating the use value of the acquired thing, may be placed in such conditions that an equivalent exchange is impossible for the objective reasons, as it is in the case of hiring workforce by a capitalist, an entrepreneur.

The relations that people enter into in the process of social production of material and spiritual benefits constitute a considerable, if not the greater, part of public relations regulated by the law. All such relations oriented to obtaining a socially useful result are determined by the specifics of the created material benefit, by the ways and methods of its creation, the requirements of economical efficiency, public and environmental safety, but remain neutral with respect to any ideological assessments, including assessments of their fair distribution. Firstly, these are the technical-production (technological) relations associated with production of any material benefits; secondly, the relations that arise and exist in the process of conducting educational activities, medical assistance, transportation and other services; thirdly, the procedural relations in the sphere of activity of the law-making bodies, as well as the court and other law enforcement bodies.

The process of production of material benefits carried out by a group of people (sometimes a very significant one) is focused on obtaining a certain result and, due to the specialization and cooperation of production, requires a high degree of co-ordination of the actions of employees. It is required to preliminary determine the sequence of technological procedures, the appropriate raw materials and other material resources, to select and arrange personnel, etc., to carry out packaging and shipment of finished products in a timely manner. Such complex and harmonious work is achieved, among other things, thanks to the system of normative legal acts (regulations on the operating procedure of structural subdivisions, job descriptions, various kinds of schedules, regulations on reporting procedures, etc.).

The regulatory prescriptions aimed at the final result of the activity contained in these acts can be efficient or inefficient, economic or uneconomic, consistent or contradictory, complete or incomplete, whatsoever, but the criterion of justice is not applicable to them. Because in the technical-production processes, there are no relations of equalization, distribution or rewarding, which fall under the criteria of justice. The above-said, of course, does not apply to the industrial economic relations (relations of ownership of tools and means of production, exchange, employer-employee relations, etc.), where, as noted earlier, the above criterion operates in full force and without any exceptions.

A significant part of normative legal acts regulating the process of organization and implementation of education and training in general and professional educational institutions (curricula, methods, education plans, state standards, regulations determining the organization order of classes, intermediate, 
final certification of students, etc.) pursues the goal of ensuring the planned and purposeful activity in the transfer of knowledge and skills and, accordingly, cannot be estimated from the position of justice or injustice. The educational, as well as the technical and production activity is also devoid of any sort of distributive relations. The educational process does not recognize the privileges and prohibitions, since the main principle of education is its common availability. All classes provided for by the state educational standard, curriculum, are oriented to everyone and are accessible to all students without any exception.

Legal relations between a medical worker and a person undergoing treatment and receiving other medical services cannot be recognized as fair or unfair. Provision of preventive, therapeutic and diagnostic, rehabilitation, prosthetic-orthopaedic and other medical assistance is carried out in order to recover or strengthen health. It is possible to achieve these goals to the extent to which the medical care that is being provided is capable of combating the disease, and, if possible, destroying the factors that destabilize human health. In this activity carried out in accordance with the current methods of medical care, regimens for taking medications and medical procedures, the correct diagnosis, the features of the course of illness, the psychological condition of patients, their willingness to fight the disease that are purely objective factors, are crucial.

If the professional activity in the field of medical care is free from any assessments in the justice-injustice criteria, then the relations with regard to the provision of medical care are a kind of distributive relations and, therefore, can be considered from such positions. In particular, it is possible to talk about the fair or unfair rules for obtaining medicines by various social groups, the rules for reception of the population by qualified specialists, the provision of medical care by leading clinics and hospitals.

Many, if not all, procedural relations remain neutral with respect to the principle of justice. For example, is it possible to assess the fairness or unfairness of the witness's call to the investigator, the participation of witnesses in the inspection of the scene of the incident, the rules that fix the forms of procedural documents, the procedure for carrying out individual actions to collect and evaluate evidence? The procedural rules focused on the achievement of a certain legally significant result, which is to establish the truth in a criminal case, all the circumstances necessary to make a reasonable and lawful verdict, provide for the rights and obligations, the implementation of which would ensure such a result. The logic of collecting and evaluating evidence in a case dictates both the set of procedures necessary for establishing the truth in the case and the system of rights and obligations that the entities participating in these procedures should have.

Simultaneously, a certain part of legal relations arises and develops not in accordance with the principles of social justice, but in spite of it. We should agree with the statement of O.I. Tsybulevskaia that not all laws, even those based on an understanding of justice, can be moral (Tsybulevskaia, 2004, p. 14).

State coercion, being a necessary condition for legal regulation, within certain limits, allows such methods of ensuring the force of law, the protection of a violated right that do not fit with the criteria of justice and morality. This, for example, is a widespread cultivation in accordance with the Federal Law "On Operative-Investigative Activities" by the police, state security of operational search activities with the participation of informants on a paid or public basis. In this case, the state even makes a sacrifice of the constitutional right of an individual to honour and dignity, since it encourages and develops a 
secret whistle-blowing, in which an informer can accuse another person before the state authorities of shady ventures he did not commit, including crimes. But this measure is involuntary, since it is impossible to conduct a successful fight against such evil as a crime without operational-search activity. The tasks of combating crime are subject to such not entirely just and moral measures as body search, pat-down, seizure of personal correspondence, etc.

Not all the norms of the civil law are successively consistent with the principle of justice. State coercion associated with the restoration of the violated rights of the owner includes a number of measures that do not harmonize well with the modern understanding of justice. Although the current civil legislation does not have the barbarous right to compensate for the missing debt by seizing a part of the debtor's body, nevertheless, it clearly and consistently defends the rights of the owner allowing, in the process of protecting this right, the application of rather harsh and not entirely friendly measures based on justice and mutual assistance. In particular, the legislation allows withdrawing from the bankrupt of all of its material and monetary resources, depriving of real estate, bank deposits and other property.

In view of the above circumstances, we must either recognize the rules of law regulated without regard to the principle of justice as non-legal, or justice - as a non-universal and non-essential feature of law. Since it is not possible to throw out a large part of legal rules outside the law for the sake of the theory of natural law, the inconsistent theory of law has to be brought into line with objective reality, and the principle of justice has to be recognized as a specific feature of the rules of law that governs only distributive relations. In any way this principle cannot apply to the entire system of law, a significant part of which is neutral to it, and some part of rules related to the sphere of the state coercion contradicts it. Meanwhile, in all legal relations, in which the principle of justice turns out to be useless and inoperative, such an essential principle of law as equivalence is successfully and fruitfully applied.

The material or spiritual benefit acquired by each participant in a legal relation appears as an equivalent payment for the fulfilled legal obligation and differs from the benefit alienated in favour of the other participant only by a consumer value. The subject is entitled to receive from the other participant in a legal relation approximately as much as it gave to it itself. The conformity of the value of the material or spiritual benefit received by the subject of the legal relation to the costs that it incurred in the process of fulfilling a legal obligation in the same legal relation, is understood as equivalence. It is this property that distinguishes the law from other ways of interaction of subjects based on force, deception or delusion, when one participant of the relation receives incommensurably more than it gives to another.

As it was shown earlier, the law may also be unfair. However, it cannot contradict the principle of equivalence under any conditions. Each participant in a legal relation receives according to the costs incurred, so not only it loses anything, but, on the contrary, acquires something, adds to what it had before. The law does not recognize another way to ensure the interested interaction of two or more persons without any violence over their will. Legal violence differs from political violence and state arbitrariness by the fact that the attractive force of the material or spiritual benefit replaces the action of external force in it.

Violence over a person is fulfilled by his own need, an irresistible desire to have what he does not have yet. A person most often enters into a legal relation purely on a voluntary basis and consciously, since this is the path for him that is most acceptable and effective. Doing something 
equivalent in the other person's favour can satisfy his need for a certain benefit, which he sees as vital. Hence the equivalence principle receives another meaning, as the equivalence of the material or spiritual benefits received by each participant in a legal relation.

It is not difficult to notice that the above definition does not contradict the previously given definition of equivalence as the compliance of a value of the material or spiritual benefit obtained by a subject of a legal relation to its costs as an obligated party in the same relation. This is the same relation, but given in different aspects, since the subject of evaluation, comparison -benefits obtained by subjects of a legal relation - remains unchanged. In the first definition, equivalence characterizes correlation of a result and the action with respect to the same subject of a legal relation, whereas in the second case - correlation of the results achieved by each participant in a legal relation. But since each participant in a legal relation receives only as much as it has reproduced and implemented in favour of the other, in order to assess the legal nature of the relation it is quite sufficient to establish the equivalence of the benefits of what one participant has received from the other. A relation can be recognized as legal if each of its participants has received benefits equivalent to the alienated ones.

At first glance the concept of "equivalence" largely coincides with the concept of "equality". Both characterize something identical, which can be inherent in different subjects, objects, and relations. But there is a fundamental difference between them.

Equality characterizes the identity of objects, phenomena and goods by any one or several of the inherent quantitative or qualitative properties, features. Citizens have equal political, social, economic rights enshrined in the Universal Declaration of Human Rights or the country's current constitution. The rules of law have the same logical structure. The bodies can have equal weight, and the distances - equal length, and so on.

Equivalence also characterizes equality, but it is equality of the inherently unequal. Persons who have the same legal status and focus on the same objects can only compete with each other, but in no way participate in the same relation. It is, for example, sellers of the same goods, buyers standing in a queue, journalists who came to a press conference with a famous person, etc. A legal relation is entered by persons, provided that they have different goals, different legal statuses and, accordingly, different objects.

In a legal relationship, everyone get what they do not have - for this they actually enter into a legal relation and give what is less important, less valuable for them in this situation. According to the Russian saying, they "get this for that". Nobody will enter into a legal relation in order to acquire what they already have. The dissimilarity of objects, for the sake of possession of which persons enter into a legal relation, generates a significant discrepancy in their rights and obligations. The rights of the seller cannot in any way coincide with the rights of the buyer and the rights of the consignee - with the rights of the carrier of its things. The coincidence of subjective rights and legal obligations of participants of a legal relation in one means the termination of any obligations.

However, if subjects of a legal relation have different rights and obligations, claim to different objects of a legal relation, then how can you make sure that the relation remains within the legal boundaries and does not represent a typical case of trickery of one subject by another or obtaining high profits not due to the exchange value of the goods, but due to the inability of another person to correctly examine the quality of the purchased goods or rendered services.

Understanding of how subjects of legal relations can determine the equivalence of their 
qualitatively different actions is a fundamental problem of the legal science and the legal practice. Not only the general ideas about the equivalence of rights and obligations in the relevant legal relation are important, but also the criteria that help to accurately and indisputably establish the equivalence of actions of the obligated party with the subjective law of the other party in the legal relation, and vice versa.

Consequently, the necessary condition for following the principle of equivalence is the search for the basis, by which the qualitatively or quantitatively different material, spiritual benefits, services or other social values can be considered equivalent. Such basis is something third in the form of a natural or artificially created scale of measurements and therefore is determined by the agreement of the parties and the current legislation or through applying some generally recognized scale, equivalent.

Under modern conditions, the most common equivalent in legal relations is money, thanks to which it is possible to establish the equivalence of rights and obligations in relations associated with the distribution of the produced goods, the provision of services, the realization of legal responsibility in the form of the duty to pay a fine, to compensate the cost of the harm caused. The same equivalent is also used in labour relations associated with the hiring of labour force, the fulfilment of tax obligations to the state, and the assessment of moral harm.

However money is not the only legal equivalent. Thus, high labour merits are adequately assessed with the help of a developed system of orders and medals, honorary titles, state prizes, while the public danger of crimes and the identity of a person who committed it through a system of punishments applied to the perpetrators.

The absence of a scale that makes it possible to make precise measurements of the equivalence of objects of legal relations has the most negative impact on the implementation of the relevant legal rules in specific relations, creates significant difficulties in determining the equality of their participants and, ultimately, creates difficult conflicts between them.

In modern legislation having a long history of its development, the problem of the equivalent measurement of objects of the corresponding legal relations, as a rule, has already received a proper theoretical and practical solution and is not as relevant as at the initial stages of the formation of law, but, nevertheless, is still topical in the legal science and practice. This is facilitated, first of all, by the practice of strengthening of the principle of equivalence in legislation without taking into account the specifics of the subject of the legal regulation.

The equivalence manifests itself most obviously in the sphere of private law. In the sphere of public law, especially in legal relations based on the principles of imperativeness, the equivalence is less pronounced, but, nevertheless, it exists losing a commercial mercantile nature of a private interest and rises to the level of the highest legal and moral values - the defence of the Motherland, the preservation of the national culture, its development in the name of progress and prosperity of the society and each of its members. A centuries-old history of the class society convincingly demonstrates that the triada person, a state and a society - exists and interacts not in the name of a certain member, but because none of the members of the triad can function and successfully develop outside this system, the interdependence on its other components.

Russian jurists, rightly emphasizing the importance and necessity of the constitutional recognition of a person, a personality, his rights and freedoms as the highest social value, still sometimes absolutize him believing that the contradictions arising between the society and 
an individual "should be resolved, as a rule, in favour of the person's interests in order to realize his rights and freedoms". Meanwhile, the recognition by the Art. 2 of the Constitution of the Russian Federation of a personality as the highest social value cannot be regarded as evidence of the unconditional and comprehensive priority of the individual's right and freedoms over the society and the state.

The essence of the Art. 2 of the RF Constitution is to protect an individual from arbitrary interference in his life by other individuals and the state. "The idea of "inalienable rights" is directed against the state as such", I.A. Pokrovskii wrote on the eve of the October Revolution, - Self-affirmation of an individual reaches its culmination point in the legal sense here. Once a mute sheep in a human herd now claims for the role of an equal power with the state with the right of sovereignty in some of its own territory" (Pokrovskii, 1998, pp. 309-310). In order to approve a person in his rights, the Constitution of the Russian Federation imposes on the state a threefold duty: to recognize, respect and effectively protect the rights and freedoms of a person and a citizen.

But the individual freedom of a personality understood in this way does not absolve it from the duty to contribute with its owns direct actions to the consolidation and development of society and the state as total entities, in the sphere of which and due to which a personality can be free and active. And again, the Constitution of the Russian Federation has a number of rules that impose specific duties on a person, the conscientious fulfilment of which is a necessary condition for the functioning of the state and society. At the same time, an individual has to compound his personal interests with the interests of the society and the state, to perform actions that are far from being realized by everyone in their universality and necessity.
A personality has a number of obligations in favour of society and the state, for without their conscientious fulfilment, the existence of neither society, nor the state is possible. The whole ensures its unity and organic integrity by subjugating all its parts, demanding from them coordinated and strictly defined actions aimed at preserving and developing the whole. The society as a total whole can maintain itself and function as a whole insofar as it manages to ensure strict compliance by all its members with their constitutional and other legal obligations in favour of the society and the state.

The state is not able to reliably protect the country, the population from the encroachment of any foreign aggressor, if it does not have a modern, combat-ready army. All social rights of an individual requiring a state material support will remain only a declaration, if the state cannot or does not allocate sufficient material and financial resources for these purposes. The bodies for the protection of law and order and the fight against crime will not be able to fulfil their tasks without reliance on active assistance of the population, including their faithful fulfilment of their duties as witnesses or experts. Conscientious fulfilment of constitutional duties by all citizens, therefore, is a guarantee of effective performance of the state and preservation of the society as a total whole.

In order for the state and society to fully and actually fulfil their obligations towards an individual, it is necessary that a person take the most active and direct part in the affairs of the state and the society, conscientiously fulfil duties assigned to him. Therefore, the constitutional and other legal duties of an individual committed in favour of the state in the public-legal relations of "power-subordination" are nothing more than an equivalent payment for their rights and the guarantee of their real action.

Thus, in order to ensure the correct assessments of the legal nature of legislation and 
other legal phenomena, first of all, it is necessary to use the universal essential feature of law - the equivalence. The principle of justice that has no universal significance can be used as an additional criterion in the evaluation of distributive and some other relations. The substitution of the principle of equivalence by the principle of justice, which takes place in the modern legal literature and legal practice, creates noticeable subjectivism in the assessments of existence, gives appearance of the law to the phenomena and processes, in fact, representing its transformed form, the anti-law.

\title{
References
}

Nersesiants, V.S. (1998). Philosophy of law. Moscow.

Pokrovskii, I.A. (1998). The main problems of civil law. Moscow.

Tsybulevskaia, O.I. (2004). Morality, law, power. Saratov.

\section{Почему право является эквивалентным}

\section{и, как правило, несправедливым}

\author{
B.M. Сырых \\ Российский государственный \\ университет правосудия \\ Россия, 117418, Москва, \\ ул. Новочеремушкинская, 69
}

\begin{abstract}
В статье обосновывается неправомерность имеющихся в юридической литературе воззрений на справедливость как сущностный признак права: признание ее всеобщности исключено, поскольку предмет правового регулирования не ограничивается сферой действия принципа справедливости, а отдельные правоотношения и вовсе ему не соответствуют (например, техникопроизводственные, образовательные, процессуальные и др.). Объекты правоотношений, во имя которых граждане и иные лииа вступают в правоотношения, являются не равными, но равноценными, эквивалентными. Принцип эквивалентности проявляется в тех случаях, когда ценность материального или духовного блага, полученного субъектом правоотношения, соответствует затратам, которые он произвел в процессе исполнения юридчческой обязанности в этом же правоотношении. В тол же время значительная часть имущественных и иных правоотношений прямо противоречит принщипу справедливости.
\end{abstract}

Ключевые слова: философия права, право, принципы права, справедливость, эквивалентность, частное право, публичное право, нравственность, антиправо.

Научная специальность: 09.00.00 - философские науки, 12.00.00 - юридические науки. 